\title{
Source, density and composition of sympagic fauna in the Barents Sea
}

\author{
OLE J. LØNNE and BJØRN GULLIKSEN
}

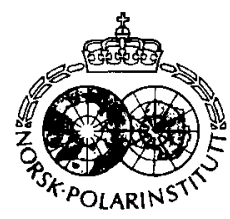

Lønne, O. J. \& Gulliksen, B. 1991: Source, density and composition of sympagic fauna in the Barents Sea. Pp. 289-294 in Sakshaug, E., Hopkins, C. C. E. \& Øritsland, N. A. (eds.): Proceedings of the Pro Mare Symposium on Polar Marine Ecology, Trondheim, 12-16 May 1990. Polar Research IO(1).

The sympagic fauna (= ice fauna) of the Barents Sea was investigated on nine different cruises in 19821988. Each cruise lasted from two to five weeks. Sampling techniques were based on scuba diving. The most abundant sympagic organisms were the polar cod (Boreogadus saida) and the three amphipods Apherusa glacialis, Onisimus sp. and Gammarus wilkitzkii.

Mean biomass-values (wet weight) of the invertebrate sympagic fauna ranged from 0 to $2 \mathrm{~g} / \mathrm{m}^{2}$. Values above $0.001 \mathrm{~g} / \mathrm{m}^{2}$ were not recorded in five of the nine cruises. This is orders of magnitude lower than mean values recorded in multi-year ice north of Svalbard and in the Fram Strait where values between 1$10 \mathrm{~g} / \mathrm{m}^{2}$ are quite common

Apherusa glacialis seemed to have the best spreading capacity of the three most conspicuous amphipods. Gammarus wilkitzkii was most dependent on a passive transport with the ice.

Sympagic amphipods play an important part in a food chain from microalgae to polar cod and marine birds in areas covered with ice, especially in areas with multi-year ice.

Ole J. Lqnne and Bjørn Gulliksen, Department of Marine Biology, Troms $\emptyset$ Mseum, University of Troms $\emptyset$, $N-9000$ Troms $\emptyset$, Norway. Present address: The Norwegian College of Fishery Science, University of Troms $\phi$. N-9000 Tromsø. Norway.

\section{Introduction}

The Barents Sea, one of the marginal seas to the Arctic Ocean, is seasonally partly covered with ice. The average water-depth is about $230 \mathrm{~m}$ (Wassmann \& Sakshaug 1987). Water depths less than $50 \mathrm{~m}$ are found on Spitsbergenbanken and in nearshore areas only. The Barents Sea is, in the north, partly separated from the Arctic Ocean proper with a small number of islands situated between Nordaustlandet (Svalbard) and Frans Josef Land.

The age and origin of the sea ice in the Barents Sea is variable. Usually it is a mixture of locally produced first-year (FY) ice and multi-year (MY) ice, in addition to the similar sea ice types imported from the Arctic Ocean. There may be considerable variation in the relationship between the different components (Vinje 1985). The ice cover reaches its maximum extent in February to May and may extend south of Bjørnøya. Most of the FY ice melts by the end of August. By that time, in most years, the ice edge has retreated to north of Kong Karls Land in the northern Barents Sea (Vinje 1985). Areas north of Svalbard and Frans Josef Land are dominated by MY ice from the perennial sea ice zone.
The word "sympagic" means "with ice", and we use this term to include all animals that live at least temporarily in or on the submerged parts of the sea ice. Species are assigned to the sympagic assemblage of animals on the basis of observations of their actual presence (temporary or permanent) in the ice or on the ice surface. Our present understanding of the structure and composition of sympagic assemblages is to a large extent based on sampling and observations using scuba techniques. Most of our data, and data previously published by others, have been gathered from areas near shore-based stations or from ships working along the rim of the Arctic basin. Water depth and the duration of the ice-covered season affect composition and density of sympagic assemblages in such areas (Carey 1985).

There are fewer data available from areas with a permanent cover of sea ice. Year-round studies from the Soviet ice drift station NP23 in the central Arctic Basin, however, have shown that a unique assemblage of species exists and utilises the ice substrate throughout its life cycle. Sympagic species therefore have been divided into an autochthonous group consisting of the permanent residents of the ice and an allochthonous group 
consisting of temporary residents (Mel'nikov \& Kulikov 1980).

The link between the sympagic assemblages occupying FY ice and assemblages associated with MY ice has attained little attention. The aim of this paper is to focus on the variations in density and relative distribution of the sympagic fauna found in the seasonally ice-covered Barents Sea and to compare our findings with similar data from the perennial sea ice zone further north.

\section{Material and methods}

The sympagic faunal communities in the Barents Sea were studied on nine different cruises in 19821988 , each lasting from two to five weeks (Gulliksen 1984; Lønne \& Gulliksen 1991a). The cruises in the Barents Sea have together spanned the months from February through October. The sympagic fauna within the perennial sea ice zone north of Svalbard and in the Fram Strait were studied on two different cruises in 1986 and 1988 (Lønne \& Gulliksen 1991b).

Sampling in the field was based on different techniques using scuba equipment. This included the use of a suction sampler especially designed for collection of organisms on rough surfaces, in brine channels and from other habitats that are difficult to reach (Lonne 1988). Also used were a plankton net with a straight upper frame suitable to haul along flat undersurfaces of the ice (Gulliksen 1984), underwater-photography, and in situ observations. To quantify the abundance of the sympagic organisms, suction samples were taken within specific time intervals. Predetermined areas of the undersurface were scraped and photographs of the organisms were taken within reference-frames of known sizes. (See Lønne \& Gulliksen 1991a, b for detailed descriptions of sampling techniques and sampling locations).

\section{Results and discussion}

Three amphipods. Apherusa glacialis, Onisimus sp. and Gammarus wilkitzkii, and the polar cod, Boreogadus saida, were the most abundant sympagic macro-organisms in the ice of the Barents Sea. Onisimus sp. is most probably $O$. glacialis only, but since it is difficult to distinguish from $O$. nanseni it is denoted as Onisimus sp. The amphipods Gammaracanthus loricatus and Isch- yrocerus anguipes were relatively rare. Nereis pelagica (epitoke stage), calanoid copepods (Calanus finmarchicus, C. glacialis), the eaphausiid Thysanoessa inermis, the amphipod Parathemisto libellula and others (Table 1) were also recorded, but we regarded these organisms at present as planktonic and not belonging to the sympagic fauna.

The most frequently occurring sympagic organism in the Barents Sea is A. glacialis. This species, which had a mean wet weight of $0.0058 \pm 0.0022 \mathrm{~g}$ in the 1988 data, is mainly attached to the lower surface of the ice and on some occasions to the vertical floe edges. It is not usually associated with brine channels or crevices in the ice.

Onisimus sp. occurred on the ice surface, but was more often found within small cracks and holes. Its mean weight in our 1988 samples were almost an order of magnitude higher than $A$. glacialis, $0.01350 \pm 0.0728 \mathrm{~g}$. In 1988 , floating algal clumps were frequently recorded in holes in the ice, and Onisimus sp. were usually associated with these. Individuals sampled in these clumps were often the same colour as the algae.

The largest of the amphipods was G. wilkitzkii, which in the Barents Sea in 1988 had a mean weight of $0.07280 \pm 0.0600 \mathrm{~g}$. Juveniles and young adults were most common in these samples. G. wilkitzkii is almost always found inside small holes or channels. If disturbed, it retracts and instantly attaches itself to the walls of the channels by the spiny appendages on pleopods six and seven.

The polar cod, B. saida, is mostly observed between sandwiched ice floes or in melting holes and crevices of the ice (Lønne \& Gulliksen 1989). All specimens captured in the ice belonged to year-class I or II. Older fish descend to greater depths during spawning (Ponomarenko 1968). The absence of other year-classes in the samples support the view that spawned polar cod do not return to the surface. No reliable values for the density of polar cod could be calculated, partly due to their patchy density and their mobility. They are difficult to collect between sandwiched ice floes, and the couple of hundred individuals we were able to catch using hand-held dip nets required several hours of diving.

\section{Variation in biomass and abundance}

The total biomass of invertebrate sympagic fauna in individual localities in the Barents Sea usually 
Table 1. The relative occurrence of species collected in the Barents Sea (SSIZ) and north of Svalbard (PSIZ).

\begin{tabular}{|c|c|c|c|c|c|c|c|c|c|c|c|}
\hline \multirow[b]{2}{*}{$\begin{array}{l}\text { Year: } \\
\text { Month: }\end{array}$} & \multicolumn{9}{|c|}{ SSIZ } & \multicolumn{2}{|c|}{ PSIZ } \\
\hline & $\begin{array}{l}1982 \\
\text { Aug. }\end{array}$ & $\begin{array}{l}1983 \\
\text { M.-J. }\end{array}$ & $\begin{array}{l}1985 \\
\text { A.-M. }\end{array}$ & $\begin{array}{l}1986 \\
\text { Apr. }\end{array}$ & $\begin{array}{l}1986 \\
\text { M.-J. }\end{array}$ & $\begin{array}{l}1987 \\
\text { F.-M. }\end{array}$ & $\begin{array}{l}1987 \\
\text { Oct. }\end{array}$ & $\begin{array}{l}1988 \\
\text { Mar. }\end{array}$ & $\begin{array}{l}1988 \\
\text { May }\end{array}$ & $\begin{array}{l}1986 \\
\text { J.-A. }\end{array}$ & $\begin{array}{l}1988 \\
\text { Sep. }\end{array}$ \\
\hline \multicolumn{12}{|l|}{ Annelida } \\
\hline \multicolumn{12}{|l|}{ Polychaeta } \\
\hline Nereis pelagica & & & & & $x$ & & & & & & \\
\hline * Harmathoinae ind. & & & & & & & & $x$ & $x$ & $x$ & \\
\hline \multicolumn{12}{|l|}{ Mollusca } \\
\hline Limacina sp. & $x$ & $x$ & & & $x$ & & & & & $x$ & \\
\hline \multicolumn{12}{|l|}{ Crustacea } \\
\hline \multicolumn{12}{|l|}{ Ostracoda } \\
\hline Ostracoda ind. & & & & & & & & & $x$ & & \\
\hline \multicolumn{12}{|l|}{ Copepoda } \\
\hline Calanus spp. & & $x \times x$ & & $x \times$ & $x \times$ & & & & & $x$ & $x$ \\
\hline \multicolumn{12}{|l|}{ Mysidacea } \\
\hline Mysis sp. & $x$ & & & & & & & & & $x$ & $x$ \\
\hline \multicolumn{12}{|l|}{ Amphipoda } \\
\hline * Apherusa glacialis & $x \times x$ & $x \times x$ & & $x$ & $x x$ & $x$ & $x$ & $x \times$ & $x \times x$ & $x \times x$ & $x \times x$ \\
\hline - Onisimus spp. & $x \times$ & $x \times$ & & $x$ & $x x$ & $x$ & $x$ & $x x$ & $x \times x$ & $x \times x$ & $x \times x$ \\
\hline${ }^{*}$ Gammarus wilkitzkii & $x \times x$ & $x$ & $x$ & $x$ & $x \times$ & $x$ & $x$ & $x x$ & $x \times$ & $x \times x$ & $x \times x$ \\
\hline - Gammaracanthus loricatus & $x$ & & & & & & & $x$ & & & $x x$ \\
\hline Parathemisto libellula & $x$ & $x$ & & $x$ & $x$ & & & $x$ & $x$ & $x$ & $x$ \\
\hline * Weyprechtia penguis & & & & & & & & & & $\times$ & \\
\hline Anonyx nugax & & & & & & & & $x$ & & & \\
\hline * Ischyrocerus anguipes & & & & & & & & $x$ & & & \\
\hline Amphipoda ind & & $x$ & & $x$ & & & & & $x$ & $x$ & $x$ \\
\hline \multicolumn{12}{|l|}{ Euphausiacea } \\
\hline Thysanoessa inermis & & & & & & $x$ & & $x$ & $x$ & & $\times$ \\
\hline \multicolumn{12}{|l|}{ Decapoda } \\
\hline Pandalus sp. & & & & & & $x$ & & $x x$ & $x$ & & \\
\hline \multicolumn{12}{|l|}{ Chaetognatha } \\
\hline Sagitta sp. & $x$ & & & & & & & & $x$ & $x$ & \\
\hline Larvacea & & & & & & & & & & & \\
\hline Larvacea ind. & & & & & & & & & $x$ & $x$ & \\
\hline
\end{tabular}

$x=$ rare (found on $<50 \%$ of the stations), $x \times=$ common (found on $>50 \%$ of the stations), $x \times x=$ abundant (common on $>50 \%$ of the stations).

- Indicate sympagic species.

varied between 0 to $1 \mathrm{~g} / \mathrm{m}^{2}$ (wet weight). The average value on a single cruise never exceeded $0.4 \mathrm{~g} / \mathrm{m}^{2}$ (Fig. 1). An exception here are four stations visited in July 1986. Average biomass values on MY ice floes, probably drifted into the Barents Sea during the summer, were estimated to be $2.0 \mathrm{~g} / \mathrm{m}^{2}$.

On five of the nine cruises, values above $0.001 \mathrm{~g} / \mathrm{m}^{2}$ were not recorded. Five of six of these cruises took place in late winter/early spring, and the investigated areas were dominated by young FY ice. The cruise in spring 1985 was special in that no sympagic fauna was recorded, with the exception of a few large specimens of Gammarus wilkitzkii near a drifting iceberg. From ice charts we observed that the ice edge was usually far north, almost at $81^{\circ} \mathrm{N}$, at the time of freezing the preceding autumn. Because of southerly winds during the winter it is probable that no old ice was transported into the Barents Sea. Therefore it is likely that MY ice was too far north of the investigated area for autochthonous sympagic animals to be able to colonise fresh ice. The highest values of biomass were recorded during years when it was possible to sample closer to MY ice. This was the case in years when enough FY ice had melted for the ship to be able to enter such areas, and in the years when we had access to remote areas by the use of helicopters.

The average biomass values from the Barents Sea were significantly lower than those recorded in MY ice north of Svalbard and in the Fram 


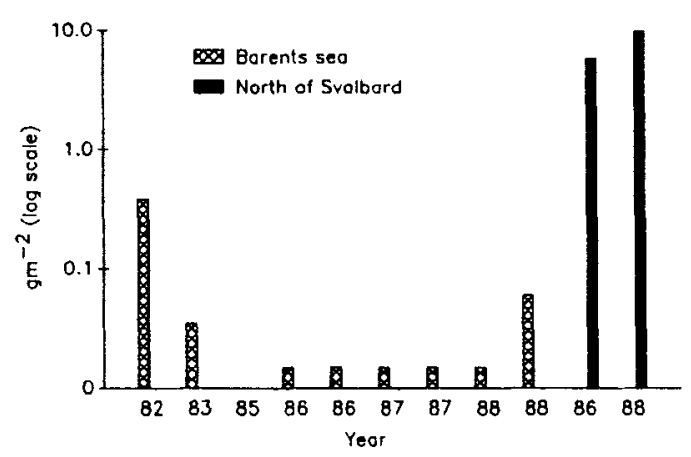

Fig. 1. Average biomass values (wet weight) from 11 cruises in the Barents Sea and north of Svalbard. First-year ice was most common in the Barents Sea. while multi-year ice dominated north of Svalbard.

Strait. In such MY ice an average of $4.7 \mathrm{~g} / \mathrm{m}^{2}$ (Fig. 1) was recorded in 1986. Biomass values recorded in 1988 were even higher, especially in the area just north of Kvitøya. Values from single locations here exceeded $50 \mathrm{~g} / \mathrm{m}^{2}$ and the average from the whole cruise was $8.3 \mathrm{~g} / \mathrm{m}^{2}$. Due to the complicated three dimensional structure of the lower ice surface found in MY ice in the perennial sea ice zone, most of the sampling was done at standardised time intervals. Biomass values per unit area were then estimated by comparing these results with quantitative photographs (Lønne \& Gulliksen 1991b).

These findings suggest that there is a transport of sympagic autochthonous faunal species from $\mathrm{MY}$ ice in the polar basin into the Barents Sea. However, no apparent N-S gradient was recorded (Lønne \& Gulliksen 1991a). The N-S pattern one might expect to find as a result of the "diffusion"

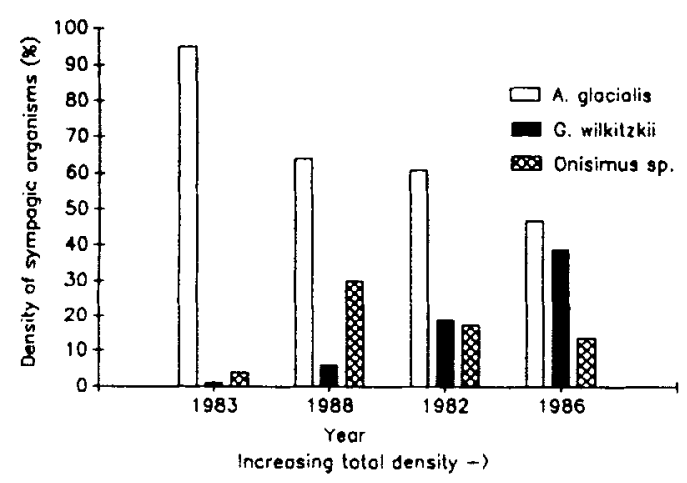

Fig. 2. Relative occurrence of the main autochthonous sympagic species. 1983. 1988 and 1982 data are from the Barents Sea and the 1986 data are from north of Svalbard. of autochthonous sympagic animals from MY ice to new habitats in FY ice might well be distorted by the complicated drift-pattern of the ice in the Barents Sea.

Because G. wilkitzkii is the least motile of the three most conspicuous autochthonous sympagic species (authors' obs.), its presence might indicate the proximity of MY ice. One should therefore expect to find higher biomass values on locations where $G$. wilkitzkii occurs compared to stations where this species is absent. This was tested on the 1983 material, where G. wilkitzkii occurred on 9 out of 33 sampled locations. The mean biomass values were significantly higher in the samples with $G$. wilkitzkii than in the samples without. This held true when the biomass of the same samples were compared after subtracting the $G$. wilkitzkii-component.

Apherusa glacialis comprised up to $90 \%$ of the sympagic specimens sampled. By comparing the years 1982, 1983 and 1988, when densities were high enough to make a relevant comparison, there was a tendency for the relative numbers of $G$. wilkitzkii to increase and $A$. glacialis to decrease as the total number of amphipods collected increased (Fig. 2). The 1983 and 1988 samples were collected in May and June, in the southern part of the Barents Sea. There were few observations of MY ice. The 1982 data were sampled in August and further north in the Barents Sea. MY ice was relatively common.

This tendency is accentuated when analysing the samples from MY ice north of Svalbard. Fewer than $50 \%$ of the specimens collected in 1986 and 1988 were $A$. glacialis and the number of $G$. wilkitzkii increased from a maximum of $20 \%$ from the Barents Sea in 1982 to almost $40 \%$ in the samples taken north of Svalbard (Fig. 2).

These findings strengthen the impression that the dominating sympagic fauna in the Barents Sea is recruited from the MY ice in the perennial sea ice zone. $A$. glacialis seems to be the most motile and was therefore found in greatest numbers far from MY ice. G. wilkitzkii is more closely related to MY ice and more dependent upon the movement of the ice to recruit new areas. The spreading capability of Onisimus sp. seems to be intermediate.

\section{Food chains}

Although diet analysis of the sympagic organisms in the Barents Sea has not been made, there are 
data on the diet of Apherusa glacialis, Onisimus glacialis and Gammarus wilkitzkii from eastern Canada (Bradstreet \& Cross 1982). All consumed microalgae, especially pennate diatoms, but $G$. wilkitzkii also ate crustaceans. This last observation corresponds well with our in situ observations of $G$. wilkitzkii and Parathemistho libellula attacking smaller crustaceans. We have also frequently sampled Onisimus sp. with clumps of algae attached to its feeding apparatus.

Polar cod diet data from the Barents Sea were collected mostly from FY ice. Here the fish fed merely on pelagic crustaceans, with calanoid copepods as the most important food (Lønne \& Gulliksen 1989). This diet is quite similar to that recorded from open waters of the Barents Sea (Hognestad 1968). However, polar cod collected in MY ice further north contained organisms more associated with the ice, and the three most abundant items were $P$. libellula, $A$. glacialis, and Onisimus sp. (Lønne \& Gulliksen 1989). The sympagic amphipod $G$. wilkitzkii was not an important food item, even though this species, in 1986 , accounted for $80 \%$ of the total biomass of the sympagic fauna where the polar cod were caught. Only a few, small specimens of $G$. wilkitzkii were found in the polar cod stomachs. The avoidance of $G$. wilkitzkii by polar cod might be due to the "spiny morphology" and the larger size of this amphipod compared to the others in the sympagic fauna.

Our results were strikingly similar to that of cod taken respectively from the undersurface of offshore landfast ice and inshore ice cracks of the eastern coast of Canada where copepods and amphipods dominated (Bradstreet \& Cross 1982). There was also a size-selection in feeding of the Canadian polar cod.

Diving seabirds such as the little auk (Alle alle), Brünnich's guillemot (Uria lomvia) and black guillemot (Cepphus grylle) are among the seabirds most likely to utilise the sympagic fauna as a food source. Sympagic amphipods and the polar cod comprised a major part of the stomach contents from these three species sampled in ice-covered parts of the Barents Sea and north of Svalbard in August 1986 (Lønne \& Gabrielsen 1992). A clear indication of food specialisation was also observed. Brünnich's guillemots had the broadest diet, but with a preference towards $G$. wilkitzkii and polar cod. Little auks fed on crustaceans only, with a preference towards the smaller species A. glacialis and Calanus sp. whereas polar cod dominated the black guillemot diet. In spring 1985, a similar diet analysis reflected the lack of sympagic invertebrate organisms on the lower ice surface at this time. Calanus finmarcicus dominated the little auk diet, while Brünnich's guillemots ate pelagic crustaceans such as $P$. libellula and Pandalus borealis and polar cod. The black guillemot fed mainly on polar cod. It is likely that the sympagic fauna play an important role in seabird diets inside or close to the perennial sea ice zone.

\section{Conclusions}

We have found a clear correlation between the occurrence of MY ice and the occurrence of sympagic fauna.

The three dominant invertebrate sympagic species Apherusa glacialis, Onisimus sp. and Gammarus wilkitzkii are probably all autochthonous sympagic species. These are sympagic organisms of which both sexes and all developmental stages occur in the ice habitat (Mel'nikov \& Kulikov 1980).

The less common Gammaracanthus loricatus and Ischyrocerus anguipes are allochthonous sympagic animals. Allochthonous sympagic species are found temporarily in the ice (Mel'nikov \& Kulikov 1980), and either planktonic, nektonic or benthic at other times of the year. $G$. loricatus and $I$. anguipes are relatively common in the benthos, and we suggest that this type of organism be called bentho-sympagic. Bentho-sympagic animals are more frequent in shallow water areas. They were few in our studies which were generally in waters deeper than $200 \mathrm{~m}$.

We have called organisms that live partly as planktonic or nekton and partly in the sympagic habitat, pelago-sympagic. The polar cod, Boreogadus saida, is such an organism.

The relative abundance of organisms varies from year to year and the relative abundance of the three most conspicuous sympagic species is not constant. A. glacialis, for instance, dominated assemblages collected in May/June 1983, but Onisimus sp. and G. wilkitzkii were more common in May/June 1986 and 1988. This is possibly due to a stronger component of FY ice in 1983 than in 1986 and 1988. A. glacialis is the most motile species and has thus the best capacity to colonise fresh ice.

Acknowledgements. - This work is part of the Pro Mare programme and has been financed by the University of Troms $\varnothing$ and 
the Norwegian Research Council for Science and Humanities (NAVF). The authors would like to thank crew and colleages On R/V LANCE, M/V POLARBJØRN. K/V NORDKAPP. K $V$ SENJA and $K / V$ ANDENES for assistance during the expeditions. We should also like to thank dive master $B$. Seim for excellent diving companionship and management of diving operations.

\section{References}

Bradstreet. M. S. W. \& Cross. W. E. 1982: Trophic relationships at high Arctic ice edges. Arctic 35(1), 1-12.

Carey. A. G., Jr. 1985: Marine Ice Fauna: Arctic. Pp. 173-190 in Horner. R. A. (ed.): Sea Ice Biora. CRC Prcss. Boca Raton, Florida

Gulliksen. B. 1984: Under-ice fauna from Svalbard waters. Sarsia 69, 17-23.

Hognestad P. T. 1968: 1. Observations on Polar cod in the Barents Sea. Rapp. P.-V. Réun. Cons. Int. Explor. Mer 158 , 126-130.

Lonne, O. J. 1988: A diver-operated electric suction sampler for sympagic ( = under-ice) invertebrates. Polar Res. 6. 135136.
Lønne, O. J. \& Gulliksen, B. 1989: Size, age and diel of polar cod. Boreogadus saida (Lepechin 1773). in ice covered waters. Polar Biol. 9, 187-191.

Lønne. O. J. \& Gulliksen. B. 1991a: On the distribution of sympagic macro-fauna in the seasonally ice covered Barents Sea. Polar Biol. 11. 457-469.

Lørne, O. J. \& Gulliksen, B. 1991b: Sympagic macro-fauna from multiyear sea-ice near Svalbard. Polar Biol. 11, 471477.

Lonne, O. J. \& Gabrielsen, G. W. 1992: Summer diet of seabirds feeding in sea-ice covered waters near Svalbard. Polar Biol. In press.

Mel'nikov. I. A. \& Kulikov, A. S. 1980: The cryopelagic fauna of the central Arctic Basin. Biol. Tsental'nogo Arkicheskogo Basseina. 97-111. (Canadian translation of Fisheries and Aquatic Sciences 4910 (1983)).

Ponomarenko. V. P. 1968: Some data on the distribution and migrations of polar cod in the seas of the Soviet Arctic. Rapp. P.-r. Réun. Cons. Int. Explor. Mer 158, 131-135.

Vinje. T. 1985: The physical environment. Western Barents sea. Drift. composition, morphology and distribution of the ice ficlds in the Barents Sea. Norsk Polarinst. Skr. $179 \mathrm{C}$. $26 \mathrm{pp}$.

Wassmann, P. \& Sakshaug, E. 1987: Barentshavets økologiske grunntrekk. Naluren 4. 151-158. 